\title{
MOBILE AUGMENTED REALITY: DESIGN PRINCIPLES FOR THE USE IN EDUCATIONAL SETTINGS
}

\author{
Luca Moser \\ University of St.Gallen \\ St. Jakob-Strasse 21, CH-9000 St.Gallen, Switzerland
}

\begin{abstract}
Mobile Augmented Reality (MAR) is increasingly used in education. MAR has the potential to motivate and engage learners, increase learning effects and change the quality and quantity of interaction during the learning process. Therefore, MAR learning settings (MARLS) design principles are needed to provide teachers and researchers with orientation knowledge MARLS. However, there is a lack of frameworks and principles to guide the design of effective MARLS. Design principles for MARLS should include technical and pedagogical aspects. In a literature review we analyzed 12 studies on MAR design and application for education to identify the design principles: 1. Usability; 2. User centeredness; 3. Basic learning theories; 4. Conscious application; 5. Cognitive overload. The principles may guide researchers and practitioners to bridge the gap between MAR innovations and real-world classrooms.
\end{abstract}

\section{KEYWORDS}

Augmented Reality, Mobile Augmented Reality, Education, Design Principles

\section{INTRODUCTION}

Augmented Reality (AR) supplements and enriches the real physical space with digital elements (Wu et al., 2013). Especially Mobile AR (MAR) applications are increasingly used in education due to the possibility to apply them with any mobile device (smartphone or tablet computer) and their cost-efficiency. MAR might soon become standard in classrooms (Akçayır and Akçayır, 2017), therefore this contribution focuses on MAR. The literature on MAR for education identified considerable potential for MAR-learning settings (MARLS) to increase engagement, motivation, learning effects and the quality and quantity of interaction of learners (Akçayır and Akçayır, 2017). MARLS allow authentic, interactive and learner-centered learning experiences (Bacca et al., 2014), a deeper knowledge acquisition, and a better application of the acquired knowledge in different contexts (Radu, 2012).

However, there is a difference between a system that supports learning and the effective and sustainable implementation of such a system in real-world classrooms (Cuendet et al., 2013). Teachers often lack the necessary media-didactical skills to use MAR and design effective MARLS (Bucher et al., 2020). Even though, multiple design principles for the creation of MAR applications have been developed, the scientific discourse identified a shortage of principles illustrating how to effectively use MAR applications to design learning settings (Kerr and Lawson, 2020; Kourouthanassis et al., 2015).

This paper addresses the aforementioned research gap. Its main goal is to identify design principles for MARLS. Because isolated knowledge about a technology and isolated knowledge about pedagogy are not sufficient to effectively use new technologies in classrooms (Mishra and Koehler, 2006), design principles should combine technological and pedagogical considerations.

The following section aggregates recent metastudies to summarize the findings of MAR research. Thereafter, a literature review on MAR design and implementation principles lays the ground to develop the MARLS design principles applying the TPACK model (Mishra and Koehler, 2006). 


\section{MAR IN EDUCATION}

Seven recent metastudies on MAR in education, condense the research of 346 studies conducted between 2006 and 2019. Because the technological advances in MAR continue and steadily change the possibilities and challenges of MAR (Cuendet et al., 2013) only metastudies conducted in the past five years were included for this overview. Table 1, however, illustrates that the included studies still date back to 2006.

Table 1. Seven metastudies on MAR in education

\begin{tabular}{lcl}
\hline Metastudy & $\begin{array}{l}\text { No of Analyzed } \\
\text { Studies }\end{array}$ & $\begin{array}{l}\text { Years of Analyzed } \\
\text { Studies }\end{array}$ \\
\hline (Akçayır and Akçayır, 2017) & 68 & $2007-2015$ \\
(Altinpulluk, 2019) & 58 & $2006-2016$ \\
(Chen et al., 2017) & 55 & $2011-2016$ \\
(Garzón et al., 2019) & 61 & $2012-2018$ \\
(Quintero et al., 2019) & 50 & $2008-2018$ \\
(Sommerauer and Müller, 2018) & 36 & $2010-2017$ \\
(Yuliono et al., 2018) & 18 & $2009-2018$ \\
\hline
\end{tabular}

The metastudies draw a concise picture of the potentials and challenges of MARLS. MAR applications can increase the motivation and engagement of learners (Yuliono et al., 2018). Positive learning effects could be identified in multiple MAR studies (Altinpulluk, 2019). Particularly, the possibility to change the perspective on learning objects and to provide new ways for learners to interact with materials, teachers and other learners, offer new possibilities to design effective learning settings (Akçayır and Akçayır, 2017). The major challenges include technological difficulties and a high complexity for teachers and learners (Garzón et al., 2019). However, most of the studies investigated the introduction of a MARL. Therefore, a "novelty effect" might have increased the enjoyment and motivation and the lack of experience might have enlarged technical and instructional challenges (Akçayır and Akçayır, 2017). With only few MARLS that are applied repeatedly, the development of design principles appears to be of high relevance to implement and investigate sustainable MALRS that do not entail these novelty effects.

\section{IDENTIFYING MARL DESIGN PRINCIPLES}

\subsection{Method}

According to the TPACK model, the design and use of digital learning settings requires, content knowledge, technological knowledge, pedagogical knowledge and the combinations of the respective knowledge types (Mishra and Koehler, 2006). Teachers' core competences lie in pedagogical knowledge and content knowledge. The combination of content knowledge with technical and pedagogical knowledge varies with the content. Consequently, we focus on the combination of technical and pedagogical knowledge to identify general MARLS design principles.

The literature review therefore focuses on the pedagogical and technical aspects of MAR for education. In an online search using the library access of the University of St. Gallen, the BASE, ERIC, Science Citation Index, Science Direct, and Scopus databases were accessed. The Boolean phrase ("design principl*" OR "design framework" OR "usability principl*") AND (educat* OR learn* OR school OR teach*) AND ("augment* reality") was used on the 9th of July 2020. The search terms had to appear in the title or abstract. This initial search led to 155 results. After filtering for online available scientific journals published between 2010 and 2020, to exclude outdated and non-reviewed contributions, 77 articles entered the analysis. After reading the 77 contributions, the twelve studies that proposed design principles or frameworks for the construction or application of MAR applications for educational purposes were analyzed to identify the design principles (Table 2). 


\subsection{Results}

Table 2. Literature review on MARLS design principles

\begin{tabular}{|c|c|c|c|}
\hline Study & Theoretical Foundation & \multicolumn{2}{|l|}{ Design Principles } \\
\hline $\begin{array}{l}\text { (Altmeyer } \\
\text { et al., } \\
\text { 2020) }\end{array}$ & $\begin{array}{l}\text { Spatial contiguity principle } \\
\text { Cognitive load theory } \\
\text { Cognitive theory of multimedia learning }\end{array}$ & \multicolumn{2}{|c|}{$\begin{array}{l}1 \text { Avoid split-attention effect } \\
2 \text { Use common technology and context }\end{array}$} \\
\hline $\begin{array}{l}\text { (Bucher et } \\
\text { al., 2020) }\end{array}$ & $\begin{array}{l}\text { Learning technology by design } \\
\text { Action-oriented didactics } \\
\text { Basic of media pedagogy } \\
\text { Basics of HCI (human-computer- } \\
\text { interaction) }\end{array}$ & \multicolumn{2}{|l|}{$\begin{array}{l}1 \text { Learning activities } \\
2 \text { Teaching activities } \\
3 \text { Interdisciplinarity }\end{array}$} \\
\hline $\begin{array}{l}\text { (Cuendet et } \\
\text { al., 2013) }\end{array}$ & $\begin{array}{l}\text { Usability of HCI settings } \\
\text { Classroom orchestration } \\
\text { Design whole learning settings, (AR only } \\
\text { a part of the whole learning setting) }\end{array}$ & $\begin{array}{l}1 \text { Integration } \\
2 \text { Empowerment } \\
3 \text { Awareness }\end{array}$ & $\begin{array}{l}4 \text { Flexibility } \\
5 \text { Minimalism }\end{array}$ \\
\hline $\begin{array}{l}\text { (Dunleavy, } \\
\text { 2014) }\end{array}$ & Intrinsic motivation & \multicolumn{2}{|c|}{$\begin{array}{l}1 \text { Enable than challenge (challenge) } \\
2 \text { Gamified story (fantasy) } \\
3 \text { See the unseen (curiosity) }\end{array}$} \\
\hline $\begin{array}{l}\text { (Kerr and } \\
\text { Lawson, } \\
\text { 2020) }\end{array}$ & $\begin{array}{l}\text { Digital storytelling } \\
\text { Physicality of learning object } \\
\text { Scaffolding } \\
\text { Informal learning }\end{array}$ & $\begin{array}{l}1 \text { Experiential theme/s } \\
2 \text { Unique narrative } \\
3 \text { Multisensory design }\end{array}$ & $\begin{array}{l}4 \text { Design for gaps } \\
5 \text { Collaboration }\end{array}$ \\
\hline $\begin{array}{l}\text { (Ko et al., } \\
\text { 2013) }\end{array}$ & Usability of mobile applications & $\begin{array}{l}1 \text { User-information } \\
2 \text { User-cognitive } \\
3 \text { User-support }\end{array}$ & $\begin{array}{l}4 \text { User-interaction } \\
5 \text { User-usage }\end{array}$ \\
\hline $\begin{array}{l}\text { (Kouroutha } \\
\text { nassis et } \\
\text { al., 2015) }\end{array}$ & Usability of mobile applications & $\begin{array}{l}1 \text { Context } \\
2 \text { To-the-task content } \\
3 \text { Transparency }\end{array}$ & $\begin{array}{l}4 \text { Feedback on } \\
\text { infrastructure } \\
5 \text { Memory }\end{array}$ \\
\hline $\begin{array}{l}\text { (Messuti et } \\
\text { al., 2015) }\end{array}$ & $\begin{array}{l}\text { Basic learning theories } \\
\text { Usability of mobile applications }\end{array}$ & \multicolumn{2}{|c|}{$\begin{array}{l}1 \text { Basis in learning theories } \\
2 \text { Simple interface and usability } \\
3 \text { Blend the environment }\end{array}$} \\
\hline $\begin{array}{l}\text { (Sommerau } \\
\text { er and } \\
\text { Müller, } \\
\text { 2018) }\end{array}$ & $\begin{array}{l}\text { Lens of theory } \\
\text { Cognitive, behavioral and constructivist } \\
\text { learning theories }\end{array}$ & $\begin{array}{l}1 \text { Mobile learning } \\
2 \text { Game based learning }\end{array}$ & $\begin{array}{l}3 \text { Experiential learning } \\
4 \text { Situated learning }\end{array}$ \\
\hline $\begin{array}{l}\text { (Stefan and } \\
\text { Moldovean } \\
\text { u, 2013) }\end{array}$ & Game based learning & $\begin{array}{l}1 \text { Playability } \\
2 \text { Emotional appeal } \\
3 \text { Player's contribution } \\
4 \text { Challenge } \\
5 \text { Curiosity }\end{array}$ & $\begin{array}{l}6 \text { Control } \\
7 \text { Fantasy } \\
8 \text { Motivation } \\
9 \text { Iteration } \\
10 \text { Scaffolding }\end{array}$ \\
\hline $\begin{array}{l}\text { (Tuli and } \\
\text { Mantri, } \\
\text { 2020) }\end{array}$ & $\begin{array}{l}\text { Usability of mobile applications } \\
\text { Generic AR design principles }\end{array}$ & $\begin{array}{l}1 \text { Cognition } \\
2 \text { Orientation }\end{array}$ & $\begin{array}{l}3 \text { Design } \\
4 \text { Support }\end{array}$ \\
\hline $\begin{array}{l}\text { (Zhao, } \\
\text { 2018) }\end{array}$ & $\begin{array}{l}\text { Interactive interface design method } \\
\text { Design analysis including user analysis, } \\
\text { requirements analysis, task analysis, } \\
\text { environmental analysis, and product } \\
\text { analysis }\end{array}$ & $\begin{array}{l}1 \text { User centeredness } \\
2 \text { Consistency } \\
3 \text { Rationality and clarity }\end{array}$ & $\begin{array}{l}4 \text { Diversity } \\
5 \text { Interactivity }\end{array}$ \\
\hline
\end{tabular}


The 54 proposed design principles were clustered to five design categories by using the concepts that were most frequently referenced in the twelve papers as theoretical basis for the design principles- usability, user centeredness, cognitive (over)load - as starting points. Because all the principles dealing with general learning theories or the inclusion of MAR-elements in the overall MARLS could not reasonably be attributed to these three categories, two more were added. The resulting five clusters reflect dominant pedagogical and technical challenges of designing MARLS:

1. Usability: Similar to other learning-applications, the MAR application that is part of an overall learning design has to be easy and appealing to use for teachers and students (Cuendet et al., 2013). Common complaints about MARLS, concern the usability of the applied MAR applications (Ko et al., 2013; Garzón et al., 2019). A good usability of the MAR application appears to be a key success factor for effective learning with MAR and depends on an appealing interface containing only relevant information and functions to handle the application (Ko et al., 2013).

2. User centeredness: Because main advantages of MARLS lie in their potential to increase the learners' motivation and engagement, the MARLS should focus on the needs and requirements of the targeted learners (Stefan and Moldoveanu, 2013). Especially the overarching motivational design and a context relevant to the learning process appear important (Dunleavy, 2014; Kerr and Lawson, 2020). Because usually, a teacher acts as the gatekeeper or designer of a learning setting, MARLS have to cover the teachers' needs, too. Particularly an easy classroom management and an efficient use of the scarce learning time has to be considered when designing MARLS (Cuendet et al., 2013).

3. Basic learning theories: Most studies mentioned that the classical learning theories still apply for MARLS (Messuti et al., 2015). Especially, experiential and gamified learning theories seem to fit well with MARLS and help to create motivational and learner-centered MARLS (Bucher et al., 2020; Dunleavy, 2014).

4. Conscious application: The MAR application usually represents only one part of a learning setting including many non-augmented activities. Therefore, the MARLS designer has to decide which activities should be augmented (Cuendet et al., 2013). Similar to planning a blended learning design, the MARLS designer has to organize and scaffold the activities to use the learning time effectively (Stefan and Moldoveanu, 2013). The small screen size of smartphones limits the possible activities and forces the MARLS designer to restrict its use to the activities where MAR may support the learning process effectively (Tuli and Mantri, 2020). Therefore, the type of AR application and technology should be chosen thoughtfully - location- or picture based, 3D or 2D objects, sound or no sound, interactivity or not.

5. Cognitive overload: Preventing cognitive overload is a major challenge when designing MARLS (Altmeyer et al., 2020). The handling of the mobile device may distract learners from the content and other tasks. Although, the cognitive load depends on the usability, and sensible scaffolding, it deserves special attention. Most studies mentioned the danger of cognitive overload of MARLS and demand special consideration for the cognitive load of students (Garzón et al., 2019) and teachers (Cuendet et al., 2013). As the cognitive load, the amount of information a person can process in their working memory, is limited (Sweller, 2011), the handling of the MAR application should be easy to allow focus on the learning content and activities, to enable effective learning (Dunleavy, 2014).

\section{CONCLUSION}

The low number of studies outlining design principles that cover pedagogical and technological aspects of MARLS illustrates the need to intensify respective research. Furthermore, the variety of studies and applications of MARLS makes it difficult to identify general design principles. The MARLS that build the foundation of the analyzed studies and metastudies vary with regard to the applied type of MAR, the learners, the content, and the media-didactical knowledge of the teachers. Therefore, it is essential to investigate and further improve the technological and pedagogical design principles by conducting educational design research (McKenney \& Reeves, 2014) projects and closely monitoring the developments in MAR technology.

The identified design principles may guide researchers and practitioners to bridge the gap between MAR innovations and real-world classrooms. However, the design principles cover only the pedagogical and technical dimensions and need to be supplemented with content specific expertise to create valuable MARLS. 


\section{REFERENCES}

Akçayır, M. and Akçayır, G., 2017. Advantages and challenges associated with augmented reality for education: A systematic review of the literature. Educational Research Review, Vol. 20, pp. 1-11.

Altinpulluk, H., 2019. Determining the trends of using augmented reality in education between 2006-2016. Education and Information Technologies, Vol. 24 No. 2, pp. 1089-1114.

Altmeyer, K., Kapp, S., Thees, M., Malone, S., Kuhn, J. and Brünken, R., 2020. The use of augmented reality to foster conceptual knowledge acquisition in STEM laboratory courses-Theoretical background and empirical results. British Journal of Educational Technology, Vol. 51 No. 3, pp. 611-628.

Bacca, J., Baldiris, S., Fabregat, R., Graf, S. and Kinshuk, 2014. Augmented Reality Trends in Education: A Systematic Review of Research and Applications. Educational Technology \& Society, Vol. 17 No. 4, pp. 133-149.

Bucher, K., Oberdörfer, S., Grafe, S. and Latoschik, M., 2020. Von Medienbeiträgen und Applikationen-ein interdisziplinäres Konzept zum Lehren und Lernen mit Augmented und Virtual Reality für die Hochschullehre. Preprint, pp. 225-238.

Chen, P., Liu, X., Cheng, W. and Huang, R., 2017. A review of using Augmented Reality in Education from 2011 to 2016. in Popescu, E., Kinshuk, Khribi, M.K., Huang, R., Jemni, M., Chen, N.-S. and Sampson, D.G. (Eds.), Innovations in Smart Learning, Lecture Notes in Educational Technology, Springer Singapore, Singapore, pp. 13-18.

Cuendet, S., Bonnard, Q., Do-Lenh, S. and Dillenbourg, P., 2013. Designing augmented reality for the classroom. Computers \& Education, Vol. 68, pp. 557-569.

Dunleavy, M., 2014. Design principles for augmented reality learning. TechTrends, Vol. 58 No. 1, pp. 28-34.

Garzón, J., Pavón, J. and Baldiris, S., 2019. Systematic review and meta-analysis of augmented reality in educational settings. Virtual Reality, Vol. 23 No. 4, pp. 447-459.

Kerr, J. and Lawson, G., 2020. Augmented Reality in Design Education: Landscape Architecture Studies as AR Experience. International Journal of Art \& Design Education, Vol. 39 No. 1, pp. 6-21.

Ko, S.M., Chang, W.S. and Ji, Y.G., 2013. Usability Principles for Augmented Reality Applications in a Smartphone Environment. International Journal of Human-Computer Interaction, Vol. 29 No. 8, pp. 501-515.

Kourouthanassis, P.E., Boletsis, C. and Lekakos, G., 2015. Demystifying the design of mobile augmented reality applications. Multimedia Tools and Applications, Vol. 74 No. 3, pp. 1045-1066.

McKenney, S. and Reeves, T. C., 2014. Educational design research. Handbook of research on educational communications and technology, Springer, New York, pp. 131-140.

Messuti, A., Wambeke, T. and Saltetti, F., 2015. Usability principles to design mobile workplace learning content. Open Journal per la formazione in rete, Vol. 15 No. 1, pp. 118-128.

Mishra, P. and Koehler, M.J., 2006. Technological pedagogical content knowledge: A framework for teacher knowledge. Teachers college record, Vol. 108 No. 6, pp. 1017-1054.

Quintero, J., Baldiris, S., Rubira, R., Cerón, J. and Velez, G., 2019. Augmented Reality in Educational Inclusion. A Systematic Review on the Last Decade. Frontiers in psychology, Vol. 10, p. 1835.

Radu, I., 2012. Why should my students use AR? A comparative review of the educational impacts of augmented-reality. 2012 IEEE International Symposium on Mixed and Augmented Reality (ISMAR), pp. 313-314.

Sommerauer, P. and Müller, O., 2018. Augmented reality for teaching and learning - a literature review on theoretical and empirical foundations. Twenty-Sixth European Conference on Information Systems (ECIS2018), Portsmouth, UK, 2018, pp. 1-17.

Stefan, L. and Moldoveanu, F., 2013. Game-based learning with Augmented Reality-from technology's affordances to game design and educational scenarios. The International Scientific Conference eLearning and Software for Education, No. 2, pp. 105-114.

Sweller, J., 2011. Cognitive load theory. Psychology of learning and motivation, Vol. 55, pp. 37-76.

Tuli, N. and Mantri, A., 2020. Usability Principles for Augmented Reality based Kindergarten Applications. Procedia Computer Science, Vol. 172, pp. 679-687.

Wu, H.-K., Lee, S.W.-Y., Chang, H.-Y. and Liang, J.-C., 2013. Current status, opportunities and challenges of augmented reality in education. Computers \& Education, Vol. 62, pp. 41-49.

Yuliono, T., Sarawanto and Rintayati, P., 2018. The Promising Roles of Augmented Reality in Educational Setting: A Review of the Literature. International Journal of Educational Methodology, Vol. 4 No. 3, pp. 125-132.

Zhao, Q., 2018. The Application of Augmented Reality Visual Communication in Network Teaching. International Journal of Emerging Technologies in Learning (iJET), Vol. 13 No. 07, p. 57. 